\title{
14. Take home pay required and taking statutory deductions into account
}

\section{PART I. BACKGROUND AND CONCEPTUAL FRAMEWORK}

Up to this point, this manual has been concerned with the income that workers need to be able to afford a basic but decent life for themselves and their family. Thus, so far, this manual has been concerned with determining take home pay required.

However, statutory deductions from pay (such as income taxes, social security taxes, and union fees) reduce take home pay and money available for day-to-day expenses. This means that two living wage estimates are needed - net living wage, which is the take home pay/disposable income required for decency, and the gross living wage, which is the gross pay required to ensure sufficient net take home pay for decency. This is shown in Figure 14.1. The difference between net and gross living wages is statutory payroll deductions and possibly income taxes.

Statutory deductions from pay are different from voluntary deductions. Voluntary deductions (such as for personal savings accounts, Christmas fund, or voluntary provident fund contribution) are similar in a sense to household expenditures. Statutory deductions are different, because they reduce disposable income available to workers to support a basic but decent life style without reducing expenses in any way. This chapter discusses how to take statutory deductions from pay into consideration to estimate a gross living wage.

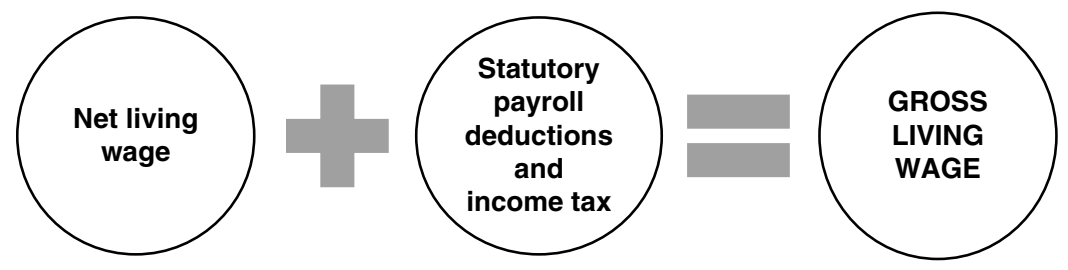

Figure 14.1 From net living wage to gross living wage 


\section{PART II. APPROACH TO CALCULATING TAKE HOME PAY NEEDED FOR A LIVING WAGE}

Previous chapters in this manual covered how to calculate the income that a worker and her/his family need for decency. This chapter discusses how much gross pay is needed for workers to have sufficient net pay/disposable income to be able to afford this basic but decent living standard.

\subsection{Statutory Deductions from Pay}

Almost all countries have statutory deductions from pay. These deductions are required by law. The types of statutory deductions differ across countries, but typical deductions include income tax, social security tax, contributions to government funds/schemes for health insurance, unemployment insurance and pension/provident funds, and mandatory union fees. Statutory deductions reduce workers' take home pay and consequently money available to support a decent life. Therefore, it is necessary to include statutory deductions in living wage estimates.

\subsubsection{Income tax}

Almost all countries impose an income tax. But in most countries, income tax is not imposed until earnings surpass a minimum income threshold (that may or may not include the value of in kind benefits). Since the minimum threshold for paying income tax in some countries is above a living wage, it is not always necessary to adjust a living wage for income tax.

\subsubsection{Other typical statutory deductions from pay}

Most countries have other statutory deductions from pay besides income tax. They come in different forms, and have different names. Whatever they are called, they reduce workers' disposable income. And they can be quite large. For example, social security taxes are $12 \%$ of pay in Vietnam. Workers in Shenzhen and Zhengzhou, China, have statutory payroll deductions of $11 \%$ for pension, unemployment insurance and medical insurance. Workers in Brazil pay $8 \%$ in social security taxes plus often mandatory union fees of more than 1\%. Workers in Ethiopia, a very poor country, pay around $6 \%$ for social security tax, plus often $2 \%$ for union fees, and would pay around another $15 \%$ in income tax at a living wage for the small city of Ziway. Examples of statutory deductions we have found in previous living wage studies include:

- Social security/social insurance

- Pension 
- Disability insurance

- Provident fund

- Unemployment insurance

- Government medical insurance

- Union dues

\subsection{Person-specific Statutory Deductions from Pay}

There are statutory and court ordered deductions from pay that are person-specific such as repayment of loans, child support, and alimony. A living wage does not need to be adjusted for such deductions.

\subsection{Voluntary Deductions from Pay}

There are various deductions from pay that are voluntary, since workers have a choice. We consider these deductions as similar to expenditures and so in a sense spent from disposable income. Therefore, the living wage does not need to be adjusted for voluntary deductions. Typical examples of voluntary deductions from pay that we have encountered include:

- Personal savings accounts

- Christmas savings fund

- Funeral fund

- Voluntary health insurance contribution

- Voluntary pension or provident fund contribution

\subsection{How to Take Statutory Deductions from Pay into Account}

To begin with, it is always useful to list all statutory payroll deductions and how they are calculated. This information is available from government sources and local enterprises. The following equation relates gross living wage to the amount of disposable income required by a worker and his/ her family to be able to afford a decent living standard (net living wage).

Gross living wage = Disposable income needed for decency (net living wage) + Statutory deductions from pay

Calculations of statutory deductions from pay are based on taxable income. Countries differ in how they calculate taxable income, the types of income taxed, and tax deductions and exemptions. Since taxes are normally applied to gross taxable pay, the net living wage needs to be 'grossed up' to account for taxes and other statutory deductions. Local enterprises 
and local representatives of certification companies are in a good position to provide information on tax laws and often to help do tax calculations.

Gross living wage can be calculated from the net living wage in three steps:

STEP 1: Subtract income exempt from taxes (e.g. possibly value of in kind benefits) from the net living wage.

STEP 2: Calculate gross living wage (excluding tax exempt income) by dividing net taxable income (from step 1) by (1-tax rate). The tax rate to use is the sum of the rates for all statutory deductions.

STEP 3: Calculate gross living wage by adding tax exempt income to the result from Step 2.

\section{PART III. EXAMPLE}

This section contains a hypothetical example of how to take statutory deductions into consideration.

\subsection{Hypothetical Country Example from a Country with Relatively Simple Tax Codes}

Assume that country $\mathrm{X}$ has four statutory deductions from pay. Taken together, they represent $12 \%$ of pay.

- Social insurance for pension $(8 \%)$

- Unemployment insurance $(1 \%)$

- Medical insurance $(2 \%)$

- Union fees $(1 \%)$

Further, assume that the net living wage is 5,000 per month, in kind benefits are valued at 500 per month and exempt from tax, and income up to 500 is exempt from tax. Therefore, the gross living wage can be calculated as follows:

STEP 1: Net taxable income $=4,000$ (net living wage 5,000 - in kind benefits 500 (not subject to tax) - tax exempt income 500).

STEP 2: Gross living wage excluding tax exempt income $=4,545$ (taxable income 4,000 divided by 0.88 (which is $1-.12$ )).

STEP 3: Gross living wage $=5,545(4,545$ from step $2+500$ in kind benefits +500 income exempt from tax) 